\title{
ANALYSIS OF FACTORS AFFECTING GUEST DECISION IN PURCHASE OF ROOM SERVICE IN HOTEL "GRAND INNA PADANG"
}

\author{
Youmil Abrian, Arif Adrian, Rian Surendra \\ Faculty of Tourism and Hospitality, Universitas Negeri Padang, Indonesia \\ abrian.yomil@fpp.unp.ac.id
}

\begin{abstract}
This paper was conducted to determine what factors encourage consumer decisions in choosing Grand Inna Hotel Padang, as well as the contribution of each of these factors. Researchers used the Grand Inna Hotel Padang because the hotel is owned by the government. Grand Inna Hotel Padang has unstable occupancy then affects to the hotel revenue. The results showed that there are 7 factors considered by consumers in rooms purchasing Grand Inna hotel Padang, the 7 factors mentioned are price factors, service factors, motivation and lifestyle factors, reference group factors, hospitality factors, MICE and brand image. Each of these factors contributes substantially to encouraging consumers to choose Grand Inna hotel Padang. The population of the study was consumers who had stayed at the Grand Inna Hotel Padang. The sampling technique used purposive sampling with a total sample is 100 respondents. The data analysis technique is factor analysis to determine the factors considered by consumers and multiple regression analysis to determine the extent factors considered affect the purchasing decision. From the results of multiple regression analysis found that the 7 factors together have a significant effect on decision in decisions purchase room service at the Grand Inna Hotel Padang.
\end{abstract}

Keywords: Analysis of factors, Customer behaviour, Decision To buy, Hotel, Marketing Mix.

\section{INTRODUCTION}

The success of West Sumatra's Government in an effort to restore the glory of Padang's tourism can be said was "successful". This can be seen from the increasing number of room occupancy at 2009-2017. Based on data collected from the Indonesian Association of Hotel and Restaurant Indonesian, the number of hotel rooms in West Sumatra after the earthquake 2019 increased from 2500 to 4000 rooms. Based on data from the Central Statistics Agency West Sumatra, the occupancy rate of star hotels in Padang in March 2017 reached 64.04 percent, increase of 11.44 points compared to February which was only 52.36 percent (BPS, 2017). 
The emergence of new hotels, repairs and revitalization a series of star hotels in Padang such as Rocky Hotel, Grand Inna Hotel, Basko Hotel, The Axana Hotel, Mercure Hotel, Whize Prime Hotel and others indicate that stakeholders believe that Padang is having a big chance for sector of tourism. It creates increasing competition. The competition is accompanied by the development of a hotel management policy strategy in order to increase hotel revenues. These developments and advancements, one of the hotels in the Padang, which is Grand Inna looks still unstable in terms of income. One of the influences on the income of Grand Inna hotel is the occupancy rate of the room that still unstable from time to time. The high and low income from a hotel business is closely related to the occupancy rate of the hotel, such as the development of occupancy rates at the Grand Inna Padang hotel which can be seen in the table below:

Table 1. Room Occupancy Rate Average at Grand Inna Padang Period July - December 2017 (Monthly)

\begin{tabular}{|c|c|c|c|c|c|c|}
\hline Bulan & Juli & Agust & Sept & Okt & Nov & Des \\
\hline Occupancy (\%) & 49,2 & 68,4 & 68,2 & 67,2 & 62,5 & 53,7 \\
\hline
\end{tabular}

Sources : Front Office Departement Grand Inna Hotel Padang 2017

Based on the table above, it can be seen that there is a decrease in occupancy rates at the Grand Inna Padang Hotel. A significant decline occurred in December 2017, where December was a high season period which should have increased the number of guests staying at the hotel. The decline in room occupancy rate resulted in a decrease in revenue Grand Inna Hotel Padang. In the period of July to December 2017, it can be seen that the occupancy rate of the room is unstable, and it does not always meet the target occupancy rate of $60 \%$ set by Indonesia Natour Hotel coorporate. The decline in room occupancy rates in the peak season period was an unusual thing when the conditions of tourism growth increased which should be followed by an increase in hotel room occupancy. In this case, the Grand Inna Padang hotel was deemed necessary to review the marketing strategy that had been carried out so that it was finally able to adapt to the competitive situation of hotels in Padang. Competition in the hotel business in the city of Padang causes consumers to have a variety of choices of hotels with prices and facilities that are also varied. By knowing the factors that drive consumers' decisions to spend the night in a hotel, it will make it easier for the hotel manager to determine the steps and implement the right marketing strategy so that in the end it can increase hotel occupancy and revenue.

Based on the background and limitations of the problems that the researchers have mentioned above, the formulation of the problem of this research is:

a). What factors are considered by consumers in purchasing room services at the Grand Inna hotel in Padang?

b). How does the factors affect decisions of consumers to choose Grand Inna Hotel Padang?

The specific purposes of this research are to identify the factors considered by consumers in purchase room services at the Grand Inna Hotel Padang. 


\section{METHODOLOGY}

The type of research conducted in this study is a type of causal associative with purpose to investigate possibility about causality by observation the result to look for factor that might be cause through spesific data.

In accordance with the research problems and expert opinions above, this study aims to provide an overview, view, and express what factors influence of customers to purchase room service for stay at Grand Inna Hotel Padang,. The design of this will be conducted in conceptual framework, it need to made a frame of mind that refers to marketing factors and factors that influence consumer behavior. These factors are described based on teory developed by Kotler, Schiffman and Kanuk (2004), so that obtained indicators from price variable, product, location, promotion, people, proces, physical support facilities, culture social environment, personal and psychology, the next one will be the foundation to factor formation, as maker factor that influence customer purchase room service at Grand Inna Padang Hotel.

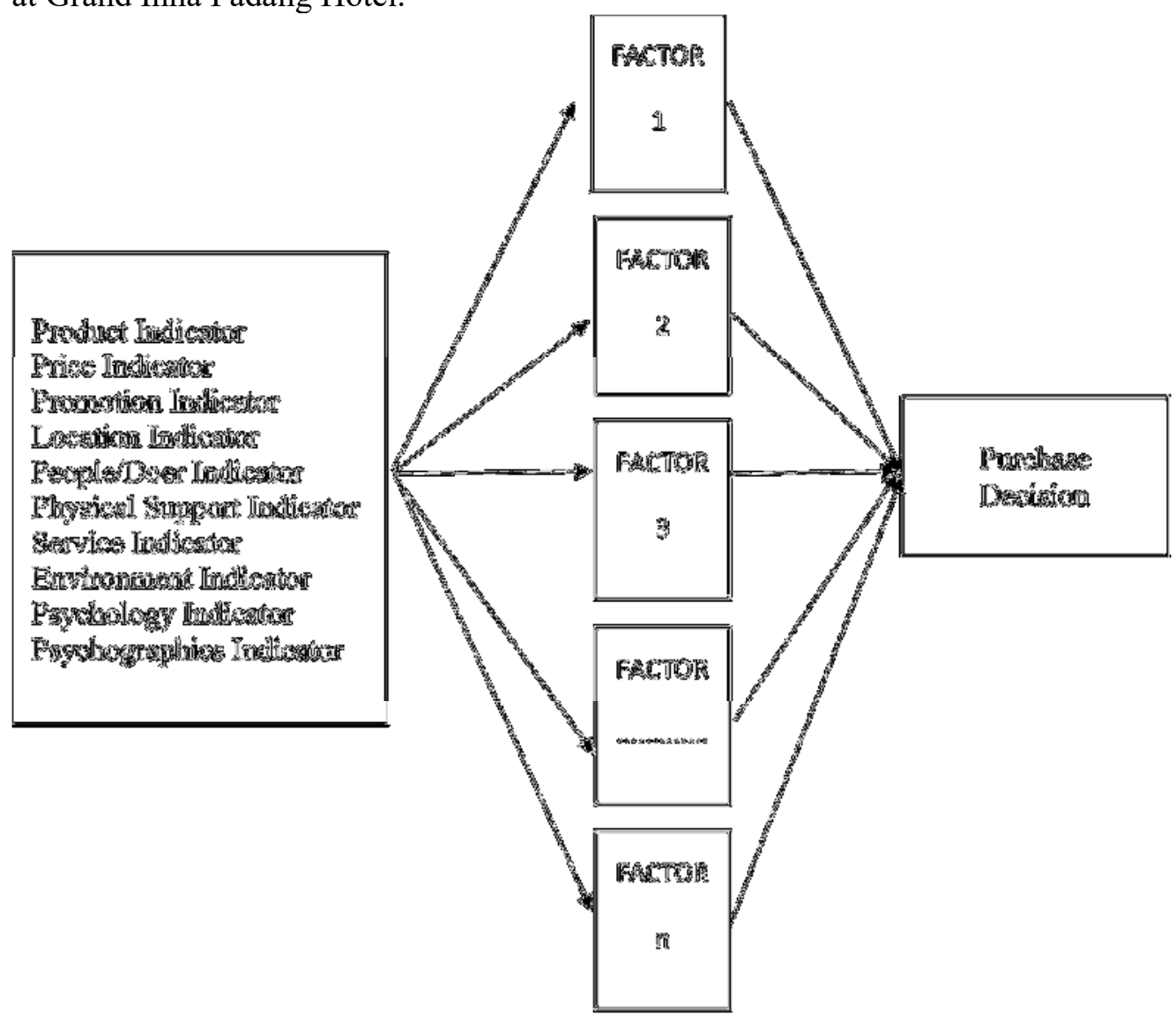

Picture 1. Conceptual Framework

The study population was guests who had been or were staying at the Grand Inna Hotel Padang. The sampling method used in this study is a non probability sampling technique, which is a sampling method that does not provide the same 
opportunity or opportunity for each element or population to be selected as a sample. While the type of non probability sampling used is purposive sampling, which is a sampling technique with certain considerations. In this study the guests selected as respondents were moderate guests and had stayed at the Grand Inna Hotel with categorized by gender, age, work, education level, and frequency visited to Grand Inna Hotel Padang. Based on considerations to facilitate research, a total sample of one hundred 100 people was determined. The number of respondents as many as 100 people is considered to be representative because it is bigger than the minimum sample limit of thirty (30) respondents.

The data collection technique used is indirect communication through the distribution of structured questionnaires. The questionnaire can be in the form of closed statements and questions given to respondents directly using a Likert scale. Questionnaire is a method of collecting data that is done by using questions or statements that must be done or answered by people who cover the target of the questionnaire. In this study, the questionnaire was used to collect data on guest decision to purchase room service Grand Inna Padang Hotel .

The data analysis technique of this study using factor analysis is determine indicator value to be included in next analysis. To conclude wheter these indicators are interconected will be indicated by Kaiser-Meyer-Olkin(KMO) value - Measure of Sampling Adequacy (MSA) and Bartlett's Test of Sphericity. In this research obtained KMO-MSA values as much 0,656. $>0.5$. This prove there is a closeness between indicator that observed and ca do fhurther testing. Value of Bartlett's Test as much 1035.302 with significant level $0,000<0,05$ that show between indicator a correlation occurs.

Determine of factor amount based on eigenvaluen, percentage of variance, and cumulative of variance. Can be shown on this table bellow :

Table 2. Determining the number of factor

\begin{tabular}{|r|r|r|r|}
\hline \multicolumn{4}{|c|}{ Eigenvalue } \\
\hline Factor & Total & \% of Variance & Cumulative \% \\
\hline 1 & 4.186 & 20.928 & 20.928 \\
2 & 3.278 & 16.388 & 37.316 \\
3 & 1.989 & 9.943 & 47.259 \\
4 & 1.726 & 8.630 & 55.889 \\
5 & 1.405 & 7.027 & 62.916 \\
6 & 1.296 & 6.481 & 69.397 \\
7 & 1.053 & 5.265 & 74.662 \\
\hline
\end{tabular}

Table 3. Results of matrix factor analysis

\begin{tabular}{|c|cl|c|}
\hline \multirow{2}{*}{ Factors } & \multicolumn{2}{|c|}{ Indicators } & $\begin{array}{c}\text { Loading } \\
\text { values }\end{array}$ \\
\hline \multirow{2}{*}{$\begin{array}{c}\text { Factor 1 } \\
\text { Price }\end{array}$} & $\mathrm{X} 4$ & Prices according to facilities & 0,923 \\
\cline { 2 - 4 } & $\mathrm{X} 5$ & Price according to service & 0,920 \\
\cline { 2 - 4 } & $\mathrm{X} 6$ & Affordable prices & 0,704 \\
\hline \multirow{2}{*}{ Factor 2 } & $\mathrm{X} 27$ & Personality & 0,868 \\
\hline
\end{tabular}




\begin{tabular}{|c|c|c|c|}
\hline \multirow{2}{*}{$\begin{array}{l}\text { Personality and } \\
\text { service }\end{array}$} & $\mathrm{X} 22$ & Consistent Service & 0,845 \\
\hline & X33 & Culture in service & 0,808 \\
\hline \multirow{3}{*}{$\begin{array}{c}\text { Factor } 3 \\
\text { Motivation and } \\
\text { lifestyle }\end{array}$} & $\mathrm{X} 35$ & Self-motivation & 0,865 \\
\hline & X29 & Social status & 0,824 \\
\hline & $\mathrm{X} 25$ & Lifestyle & 0,450 \\
\hline \multirow{2}{*}{$\begin{array}{c}\text { Factor } 4 \\
\text { Reference group }\end{array}$} & X34 & Influence of friends & 0,915 \\
\hline & $\mathrm{X} 28$ & Family & 0,878 \\
\hline \multirow{2}{*}{$\begin{array}{c}\text { Factor } 5 \\
\text { Hospitality }\end{array}$} & $\mathrm{X} 21$ & Friendly employees & 0,908 \\
\hline & $\mathrm{X} 26$ & Hospitality & 0,890 \\
\hline \multirow{4}{*}{$\begin{array}{c}\text { Factor } 6 \\
\text { MICE }\end{array}$} & $\mathrm{X} 11$ & $\begin{array}{l}\text { Implementation of national and } \\
\text { international events }\end{array}$ & 0,667 \\
\hline & $\mathrm{X} 2$ & Privileges of the Ballroom & 0,665 \\
\hline & $\mathrm{X} 18$ & $\begin{array}{l}\text { Services that are different from } \\
\text { competitors }\end{array}$ & 0,661 \\
\hline & $\mathrm{X} 31$ & Support work activities & 0,616 \\
\hline \multirow{3}{*}{$\begin{array}{l}\text { Factor } 7 \\
\text { Image }\end{array}$} & $\mathrm{X} 23$ & Employee skills & 0,799 \\
\hline & $\mathrm{X} 19$ & Useful facilities & 0,619 \\
\hline & $\mathrm{X} 24$ & Consumer perception & 0,549 \\
\hline
\end{tabular}

Based on tabe above, can be seen that there are 7 factors influence consumer in purchase of room service at Grand Inna Hotel Padang. The factors formed are given name based on highest loading in that factors and the meaning of each indicator.

\section{RESULTS AND DISCUSSION}

The results of processing the characteristics of respondents based on gender, information was obtained that the majority of respondents as much as $59 \%$ were men, while as many as $41 \%$ were women and the majority of respondents were $2 \%$ aged 18 years, $56 \%$ aged $18-34$ years, $31 \%>35-54$ years old. $11 \% 55$ years. Then from the number of times staying, it was obtained that the majority of respondents as many as $63 \%$ of new guests stayed 1 time, $37 \%$ of guest never stay just visit. Then from the job of respondents $2 \%$ were students, $38 \%$ were government employees, $44 \%$ were privates employee, $7 \%$ were housewife, and $9 \%$ others.

Based on the research problem formulation stated earlier, namely to find out the extent of the influence of the factors that influence the decision to purchase room services at the Grand Inna Padang hotel:

Tabel 4. Regression coefficient

\begin{tabular}{|ll|c|c|c|c|}
\hline Model & $\begin{array}{c}\text { Koefisien } \\
\text { Regresi }\end{array}$ & $\begin{array}{c}\text { Standar } \\
\text { Error }\end{array}$ & $\begin{array}{c}\text { Nilai t } \\
\text { hitung }\end{array}$ & $\begin{array}{c}\text { Level } \\
\text { Sig }\end{array}$ \\
\hline X1 & Price & 13.700 & 2.990 & 4.583 & .000 \\
\hline X2 & $\begin{array}{l}\text { Personality and } \\
\text { Service }\end{array}$ & .408 & .118 & 3.458 & .001 \\
\hline
\end{tabular}




\begin{tabular}{|ll|c|c|c|c|}
\hline X3 & $\begin{array}{l}\text { Motivation and } \\
\text { Lifestyle }\end{array}$ & .637 & .140 & 4.545 & .000 \\
\hline X4 & $\begin{array}{l}\text { Reference and } \\
\text { Group }\end{array}$ & .235 & .215 & 1.093 & .277 \\
\hline X5 & Hospitality & .232 & .190 & 1.221 & .225 \\
\hline X6 & MICE & .449 & .152 & 2.957 & .004 \\
\hline $\mathrm{X} 7 \quad$ Image & .041 & .147 & .279 & .021 \\
\hline $\mathrm{R}=0,587$ & \multicolumn{5}{|c|}{$\begin{array}{c}\text { F hitung }=6,901 \\
\text { Level sig }=0,000\end{array}$} \\
$\mathrm{R}^{2}=0,344$ \\
Adjusted R Squere $=0,294$
\end{tabular}

From the table above it can be seen that the results of the determination coefficient are known $\mathrm{R} 2=0,344$ or $34,4 \%$. This means that the contribution to the seven independent variables in this study amounted to $34,4 \%$. The regression equation that can be made in this study are:

$Y=13,700+0,408 X 1+0,069 X 2+0,637 X 3+0,235 X 4+0,232 X 5+0,449$ $X 6+0,041 X 7$

From the results of multiple linear regression tests that have been done can be concluded that, from the 7 (seven) variables together have a significant effect on room service purchase decisions at the Grand Inna Padang hotel. From the 7 (seven) variables there are 4 (four) variables that have a significant effect, namely the variable Price, Motivation and Lifestyle, MICE and Image. While 3 (three) variables have no significant effect, namely the Personality and Service variables, Reference Group and Hospitality.

\section{CONCLUSION}

Based on the results of the research that has been done, it can be concluded that:

1. Based on factor analysis, the factors that influence guest decisions in purchasing room services at the Grand Inna Padang hotel are 44 indicators to see their influence on guest decisions in purchasing hotel room services. Tn hese indicators were analyzed using factor analysis to reduce data into a simple data structure to be interpreted, and then obtained 20 factors that were considered in the guest decision to buy hotel room services at Grand Inna Padang. The factors considered in the guest decision to buy hotel room services at Grand Inna Padang are as follows:

- The price factor is most considered by guests, because it has the greatest eigenvalue and variable diversity.

- The service factor, which is second only to guests.

- Motivation and lifestyle factors are in the third place considered by guests.

- The reference group factor is in fourth place considered by the guest.

- The hospitality factor, ranked fifth, was considered by guests.

- The MICE factor, ranked sixth, was considered by guests.

- Image factor, is in the last order of the factors considered by guests in the guest decision to buy hotel room services at Grand Inna Padang. 
2. Based on the results of multiple regression analysis obtained a significant effect from 7 factors on the decision of guests to buy hotel room services at Grand Inna Padang together.

3. Based on the results of multiple regression analysis, the influence of these seven factors was obtained on the decision of guests to buy hotel room services at Grand Inna Padang as follows:

1) The price factor has a positive and significant effect on the decision of guests to buy hotel room services at Grand Inna Padang.

2) The service factor did not significantly influence the guest decision to buy hotel room services at Grand Inna Padang

3) Motivational factors and styles have a positive and significant effect on the decision of guests to buy hotel room services at Grand Inna Padang.

4) The reference group factor did not significantly influence the guest decision to buy hotel room services at Grand Inna Padang.

5) The hospitality factor has no significant effect on guests' decision to buy hotel room services at Grand Inna Padang

6) The MICE factor has a positive and significant effect on the decision of guests to buy hotel room services at Grand Inna Padang.

7) Image factor has a positive and significant effect on the decision of guests to buy hotel room services at Grand Inna Padang.

Based on the discussion stated above there are still many things that must be considered by the Grand Inna Padang hotel to increase the level of visits of guests who stay, The suggestions that can be given are as follows:

1. The Grand Inna hotel in Padang needs to maintain a competitive price advantage with competitors.

2. The Grand Inna Hotel Padang should be able to maintain and improve the services provided to guests who are cooperative (co-operative) especially in providing facilities that support event and convention activities.

3. Developing superiority of MICE (Meeting, Incentive, Convention, Exhibition) products which are the main market segments (government customers) at Grand Inna padang hotels.

4. Maintaining and developing the image of the hotel (hotel convention) that has been formed considering the competition for the following years.

5. Strengthening cooperation with government agencies and other agencies that tend to actively engage in MICE activities (Meeting, Incentive, Convention, Exhibition).

\section{REFERENCES}

Adrian, Payne. 2001. Service Marketing Pemasaran Jasa. Yogyakarta C. Mowen, John. Michael Minor. 2002. Perilaku Konsumen. Jakarta. Erlangga

Kotler dan Keller, (2007), Marketing Management jilid 2, New Jersy: prentice Hall Inc

Kotler dan Gary Armstrong, (2008), prinsip-prinsip pemasaran edisi 12, Erlangga : Jakarta.

Kotlerdan Keller. 2009. ManajemenPemasaran. Jilid I. Edisike 13 Jakarta: Erlangga 
Kotler, Philip dan Gary armstrong, 2009, Prinsip-Prinsip Pemasaran, Edisi 12, jilid 2,Jakarta: Erlangga

Schiffman, Leon.G. dan Kanuk, Leslie. 1994. PerilakuKonsumen. Jakarta: PT. Indeks

Schiffman and Kanuk. 2004. Perilaku Konsumen.Edisi 7. Prentice Hall. Jakarta.

Umar, Husein. 2003. Riset Pemasaran dan Prilaku Konsumen, Gramedia Pustaka Utama, Jakarta. 